\title{
PENINGKATAN KINERJA MANAJEMEN PENGENDALIAN ASET TETAP KABUPATEN PURBALINGGA
}

\author{
Performance Improvement of Fixed Asset Controll Management of Purbalingga Regency
}

\author{
Faqikh Andri Rokhmadi', Lukman Mohammad Baga'2, Nirwan Ristiyanto ${ }^{3}$
}

\begin{abstract}
1Staf Bidang Infrastruktur dan Pengembangan Wilayah Badan Perencanaan Pembangunan Daerah Kabupaten Purbalingga. Email : faqikh1000@gmail.com

2Staf Pengajar Departemen Agribisnis, Fakultas Ekonomi dan Manajemen. IPB. Email : lukmanmb@yahoo.com 3Staff Pengajar Pusat Pendidikan dan Pelatihan Pengawasan (Pusdiklatwas), Badan Pengawasan Keuangan dan Pembangunan RI. Email: nirwanristiyanto@yahoo.com
\end{abstract}

\begin{abstract}
The Government of Purbalingga Regency during the years 2011-2015 have received qualified opinion (WDP) from The Supreme Audit Agency (BPK) on the results of the audit of its financial statements. They are many problems in the presentation of fixed assets in their financial statements. This study aims to: (1) to analyze the existence of administration system of fixed asset in Purbalingga regency; (2) to analyze the weaknesses of administration system of fixed asset in Purbalingga regency; and (3) to formulate recommendation for improvement of administration system of fixed asset in Purbalingga regency. Formulation of strategy is done using SWOT analysis and strategic architecture. Then, the proposed strategies for improving the fixed asset administration system are the completion of fixed asset issues, improvement of inter-institution cooperation in asset management, improvement of human resources competence in asset management, improvement of compensation and rewards on the human resources performance in asset management, improvement of intersinstitution coordination in asset management, implementation of action plan through escorting the follow-up audit findings by the Inspectorate, implementation of an action plan through census and reconciliation of asset data on a regular basis, and the implementation of an action plan through enhancement of the role of the Inspectorate in safeguarding asset.
\end{abstract}

Keywords : Financial Statement, Fixed Asset, Strategic Architecture, SWOT Analysis

\begin{abstract}
ABSTRAK
Pemerintah Kabupaten Purbalingga selama tahun 2011 sampai dengan tahun 2015 mendapatkan opini Wajar Dengan Pengecualian (WDP) dari Badan Pemeriksa Keuangan (BPK) atas hasil audit laporan keuangannya. Terdapat berbagai permasalahan pada penyajian aset tetap dalam laporan keuangan. Penelitian ini bertujuan untuk: (1) menganalisis tinjauan keberadaan sistem kegiatan penatausahaan aset tetap Kabupaten Purbalingga; (2) menganalisis berbagai kelemahan sistem kegiatan penatausahaan aset tetap Kabupaten Purbalingga; dan (3) merumuskan rekomendasi perbaikan sistem kegiatan penatausahaan aset tetap Kabupaten Purbalingga. Perumusan strategi dilakukan dengan menggunakan analisis SWOT dan arsitektur strategi. Selanjutnya, strategi yang diusulkan dalam upaya perbaikan sistem kegiatan penatausahaan aset adalah penuntasan permasalahan aset tetap, peningkatan kerjasama antar lembaga dalam pengelolaan aset, peningkatan kompetensi SDM pengelola aset, perbaikan kompensasi dan penghargaan atas prestasi kerja dari SDM pengelola aset, peningkatan koordinasi antar lembaga dalam pengelolaan aset, pelaksanaan action plan melalui pengawalan pelaksanaan tindak lanjut temuan audit oleh Inspektorat, pelaksanaan action plan melalui sensus dan rekonsiliasi data aset secara rutin, pelaksanaan action plan melalui peningkatan peranan Inspektorat dalam pengamanan aset.
\end{abstract}

Kata Kunci: Laporan Keuangan, Aset Tetap, Arsitektur Strategi, Analisis SWOT

\section{PENDAHULUAN}

Penyelenggaraan otonomi daerah bertujuan untuk menciptakan tata kelola pemerintahan yang baik (good governance), transparan dan akuntabel. Upaya konkrit yang harus dilakukan oleh pemerintah daerah (pemda) adalah menyusun Laporan Keuangan Pemerintah Daerah (LKPD) tepat waktu setiap tahun. LKPD disusun dan disajikan sesuai dengan Standar Akuntansi Pemerintahan (SAP). LKPD merupakan suatu bentuk pertanggungjawaban pemda kepada stakeholder, yang di dalamnya mencakup berbagai macam pekerjaan yang 
membutuhkan keuangan, termasuk komponen aset yang tercermin dalam neraca daerah (Yusuf 2015).

Kabupaten Purbalingga adalah salah satu kabupaten di Provinsi Jawa Tengah yang masih meraih opini Wajar Dengan Pengecualian (WDP) dari tahun 2011 hingga 2015 dari Badan Pemeriksa Keuangan (BPK). Salah satu penyebabnya adalah penatausahaan aset tetap yang tidak tertib administrasi dan tidak tertib fisik barangnya. Hal ini menyebabkan penyajian nilai aset tetap pada laporan neraca tidak dapat diyakini kewajarannya.

Sudah banyak peraturan yang mewajibkan pemda untuk menyelenggarakan penatausahaan dalam pengelolaan aset yang baik, antara lain:

1. Peraturan Pemerintah (PP) Nomor 6 Tahun 2006 tentang Pengelolaan Barang Milik Negara/Daerah, yang selanjutnya direvisi dengan PP Nomor 27 Tahun 2014;

2. PP Nomor 24 Tahun 2005 tentang SAP, yang selanjutnya direvisi dengan PP Nomor 71 Tahun 2010;

3. Peraturan Menteri Dalam Negeri (Permendagri) Nomor 17 Tahun 2007 tentang Pedoman Teknis Pengelolaan Barang Milik Daerah, yang selanjutnya direvisi dengan Permendagri Nomor 19 Tahun 2016.

Didalam peraturan tersebut telah diatur secara jelas tentang pengelolaan aset yang baik, bahkan sampai hal-hal yang rinci, seperti: contoh-contoh formulir yang harus diisi, beserta petunjuk pengisiannya, mulai dari tahap perencanaan, pengadaan, sampai tahap penghapusan aset daerah.

Berdasarkan laporan hasil pemeriksaan BPKdari tahun 2011 hingga 2015, bahwa pengelolaan aset tetap di Pemerintah Kabupaten (Pemkab) Purbalingga masih dinyatakan buruk. Buruknya pengelolaan aset tersebut ditandai dengan banyaknya temuan audit BPK terhadap LKPD Kabupaten Purbalingga.

Berdasarkan hal tersebut, rumusan masalah dalam penelitian ini yaitu: 1) Bagaimana tinjauan keberadaan sistem kegiatan penatausahaan aset tetap Pemkab Purbalingga?; 2) Berbagai kelemahan apa saja pada sistem kegiatan penatausahaan aset tetap Pemkab Purbalingga?; dan 3) Bagaimana rekomendasi perbaikan sistem kegiatan penatausahaan aset tetap Pemkab Purbalingga?

Mengacu pada rumusan masalah tersebut, maka tujuan penelitian ini adalah untuk: 1) Menganalisis tinjauan keberadaan sistem kegiatan penatausahaan aset tetap Pemkab Purbalingga; 2) Menganalisis berbagai kelemahan sistem kegiatan penatausahaan aset tetap Pemkab Purbalingga; dan 3) Merumuskan rekomendasi perbaikan sistem kegiatan penatausahaan aset tetap pada Pemkab Purbalingga.

\section{METODE PENELITIAN}

Penelitian dilakukan pada Pemkab Purbalingga beserta Perangkat Daerah (selanjutnya disebut SKPD) yang ada dibawahnya. Penelitian secara khusus dengan Bidang Akuntansi dan Aset pada Badan Keuangan Daerah (Bakeuda) yang memiliki tugas pokok pengelolaan aset daerah dan Kantor Inspektorat selaku satuan pengawas intern. Waktu penelitian adalah bulan Maret 2017 sampai dengan Juni 2017.

Adapun jenis data yang digunakan dalam penelitian ini adalah data primer dan data sekunder. Data primer diperoleh dari Bakeuda/DPPKAD berupa data aset, data action plan, Peraturan Daerah (Perda) maupun Peraturan Bupati terkait pengelolaan aset. Data sekunder diperoleh berupa regulasi, data BPS, laporan hasil pemeriksaan BPK atas LKPD Kabupaten Purbalingga dari tahun 2011 hingga 2015. Selanjutnya, teknik pengumpulan data dilakukan dengan cara wawancara (indepth-interview) dan penyebaran kuesioner secara purposive kepada pengelola aset di 11 SKPD. SKPD yang dipilih adalah SKPD yang mengelola aset tetap dengan nilai lebih dari 18 milyar rupiah per 31 Desember 2015. 


\section{Metode Pengolahan dan Analisis Data}

Untuk menjawab tujuan pertama penelitian, metode analisis yang dipakai adalah deskriptif. Kegiatan analisis tinjauan keberadaan sistem kegiatan penatausahaan aset tetap Pemkab Purbalingga mencakup: 1) Identifikasi penatausahaan aset tetap; 2) mekanisme penatausahaan aset tetap; 3) Pengawasan, monitoring dan evaluasi terhadap proses penatausahaan aset tetap; dan 4) Dampak proses penatausahaan aset. Selanjutnya, untuk menjawab tujuan kedua dipakai metode analisis deskriptif. Berbagai kelemahan sistem kegiatan penatausahaan aset tetap yang ada dalam laporan hasil pemeriksaan BPK dibuatkan ringkasan. Untuk memperkuat ringkasan tersebut, maka diperlukan wawancara terhadap Kepala Bidang Akuntansi dan Aset pada Bakeuda serta pejabat pada Kantor Inspektorat Kabupaten Purbalingga selaku satuan pengawas intern.

Kemudian untuk menjawab tujuan terakhir dipakai metode analisis SWOT dan Arsitektur Strategi. Perumusan strategi dilakukan dengan mengidentifikasi faktor internal (kekuatan dan kelemahan) dan faktor eksternal (peluang dan ancaman). Berdasarkan identifikasi tersebut dirumuskan strategi untuk memanfaatkan kekuatan dan peluang dalam meminimalisir dampak yang timbul akibat kelemahan dan ancaman yang ada (Rangkuti 2006). Strategi tersebut dapat diterapkan dalam perbaikan sistem kegiatan penatausahaan aset tetap Pemkab Purbalingga. Selanjutnya, untuk mencapai sasaran dirumuskan program-program yang akan dilakukan dan program tersebut dilaksanakan secara bertahap yang dituangkan dalam sebuah peta arsitektur strategik.

\section{HASIL DAN PEMBAHASAN}

\section{Tinjauan Keberadaan Sistem Kegiatan Penatausahaan Aset Tetap}

Sistem pengelolaan aset berpedoman pada Surat Keputusan Bupati Purbalingga Nomor 180/9802/XI/2016 tanggal 30 November 2016 perihal Pemberlakuan PP
Nomor 27 Tahun 2014 dan Permendagri Nomor 19 Tahun 2016 di wilayah Kabupaten Purbalingga serta penghentian pelaksanaan Perda Nomor 8 Tahun 2011. Surat Keputusan Bupati tersebut adalah tindak lanjut dari Keputusan Gubernur Jawa Tengah Nomor 180/89 Tahun 2016 tentang Pembatalan Perda Nomor 8 Tahun 2011, karena keseluruhan materi muatan Perda bertentangan dengan PP Nomor 27 Tahun 2014 dan Permendagri Nomor 19 Tahun 2016. Permendagri Nomor 19 Tahun 2016 antara lain mengatur tentang kewenangan dan struktur pengelolaan aset daerah. Kewenangan pengelolaan aset ada pada Sekretaris Daerah selaku pengelola barang dan dibantu oleh Kepala Bakeuda selaku pembantu pengelola barang/pejabat penatausahaan barang, dan Kepala SKPD selaku pengguna barang dengan membawahi pengurus dan penyimpan barang. Namun, pelaksanaan pengelolaan aset tidak sesuai dengan ketentuan, antara lain: lemahnya koordinasi antara Bakeuda dengan Inspektorat dalam tindak lanjut temuan audit BPK, kurangnya pengawasan atas pelaksanaan pengelolaan aset oleh Kepala SKPD kepada Sumber Daya Manusia (SDM) pengelola aset, dan kurang optimalnya kegiatan sensus aset dan rekonsiliasi data aset.

Dalam kegiatan penatausahaan aset daerah, Pemkab Purbalingga menggunakan aplikasi Sistem Informasi Manajemen (SIM) aset berbasis akrual milik Dinas Pendapatan dan Pengelolaan Aset Daerah (DPPAD) Provinsi Jawa Tengah. Penggunaan aplikasi SIM aset tersebut telah mendapatkan persetujuan dari Kepala DPPAD Provinsi Jawa Tengah pada bulan Mei 2015. Selanjutnya, untuk pekerjaan pengembangan dan pemeliharaan SIM aset dilakukan oleh CV. SEML Semarang.

Sekalipun suatu sistem yang telah dirancang dengan baik, namun dalam penerapannya tidak dilaksanakan sesuai ketentuan, maka hasil yang didapatkan tidak sesuai dengan tujuan yang diharapkan. Salah satu penyebabnya adalah kompetensi SDM yang belum memadai. Hubungan yang signifikan pengaruh 
kualitas aparatur daerah, regulasi dan sistem informasi terhadap manajemen aset telah diteliti oleh Azhar et al. (2011) pada pengelolaan aset di Kota Banda Aceh. Selanjutnya, hubungan yang signifikan pengaruh kualitas SDM pengelola aset terhadap manajemen aset juga telah diteliti oleh Wonggow et al. (2014) pada pengelolaan aset di Kota Manado.

Proses penatausahaan aset dilakukan oleh pengurus barang di SKPD dan Bidang Akuntansi dan Aset pada Bakeuda yang bertindak sebagai koordinator penatausahaan aset. Pengguna barang harus melakukan pencatatan aset daerah ke dalam Daftar Barang Pengguna (DBP) menurut penggolongan dan kodefikasi aset. Pencatatan aset daerah dimuat dalam Kartu Inventaris Barang (KIB). Pembantu pengelola barang melakukan rekapitulasi atas pencatatan dan pendaftaran aset daerah dalam Daftar Barang Milik Daerah (DBMD). Selain itu, pengurus barang berkewajiban untuk menyusun dan menyampaikan Laporan Barang Pengguna Semesteran (LBPS), Laporan Barang Pengguna Tahunan (LBPT) pada akhir tahun pelaksanaan APBD, serta laporan inventarisasi/sensus 5 (lima) tahunan yang telah disetujui oleh Kepala Perangkat Daerah (SKPD) selaku Pengguna Barang untuk selanjutnya disampaikan kepada Bupati cq Kepala Bakeuda.

Pengawasan, monitoring dan evaluasi terhadap proses penatausahaan aset dilakukan oleh pejabat pengelola aset secara berjenjang sesuai dengan tingkat kewenangan yang dimiliki. Pengurus barang SKPD mencetak pelaporan (output) yang dihasilkan dari SIM aset dan membubuhkan tanda tangan. Selanjutnya, Kepala Subbagian Umum/Kepala Subbagian Tata Usaha SKPD, Sekretaris SKPD dan Kepala SKPD memeriksa laporan tersebut secara berjenjang dan sampling, baik secara administrasi maupun fisik/wujud barangnya. Jika dinyatakan lengkap, maka Kepala SKPD membubuhkan tanda tangan. Namun, dalam pelaksanaannya belum semua kolom/field dalam Kartu Inventaris Barang
(KIB) diisi oleh pengurus barang. Sehingga pengguna informasi sulit mengidentifikasi dan menelusuri keberadaan fisik/wujud barangnya. Hal ini tidak sesuai dengan ketentuan peraturan pengelolaan aset. Pengaruh tanggungjawab SDM pengelola aset terhadap manajemen aset telah diteliti oleh Nancy (2015) pada Dinas Pendidikan, Pemuda dan Olahraga Kabupaten Sigi.

Proses penatausahaan aset yang dilakukan dengan tertib, akan mempermudah SKPD dalam membuat laporan neraca SKPD, dan mempermudah Bakeuda selaku Pejabat Pengelola Keuangan Daerah dalam menyusun laporan neraca pemda. Namun, pelaksanaan pengelolaan aset tidak sesuai dengan ketentuan, antara lain: 1) 37 persen aset tanah yang belum bersertifikat; 2) Masih terdapat aset tanah yang belum tercatat; 3 ) Aset tercatat ganda dengan Pemprov Jawa Tengah; 4) Pemanfaatan aset tanah tanpa perjanjian tertulis; 5) Aset gedung yang telah dihapuskan, tetapi masih tercatat; 6) Aset gedung tidak sesuai dengan kondisi fisik dilapangan; 7) 53 persen ruas jalan tidak dilengkapi informasi terkait lokasi, panjang, dan lebar jalan; 8) Kegiatan pemeliharaan jalan tidak dikapitalisasi ke aset induknya. Hal ini menunjukkan bahwa pelaksanaan kegiatan penatausahaan aset tetap di Kabupaten Purbalingga masih buruk.

\section{Berbagai Kelemahan Sistem Kegiatan Penatausahaan Aset Tetap}

Dari hasil analisis atas temuan empiris dilapangan dan wawancara, bahwa pelaksanaan kegiatan penatausahaan aset terdapat berbagai kelemahan, antara lain: 1) Tidak adanya prosedur SOP yang rinci dan tertulis pada kegiatan penatausahaan aset tetap, sehingga terjadinya perbedaan persepsi dan langkah-langkah dalam kegiatan penatausahaan aset tetap; 2) Kurang optimalnya kinerja tim pengarah dan tim teknis penataan dan pengelolaan aset, sehingga pengelolaan aset tidak tertib; 3) Kurangnya pengawasan pelaksanaan pekerjaan oleh Kepala SKPD kepada SDM pengelola aset; 4) Kegiatan pengamanan 
terhadap aset belum berjalan secara tertib; 5) Kegiatan pemeliharaan terhadap aset belum direncanakan secara tertib; 6) Lemahnya koordinasi antara SKPD yang mengelola anggaran belanja modal dan DPPKAD yang mengelola aset dalam kegiatan rekonsiliasi belanja modal; 7) Belum ada aturan tertulis tentang syaratsyarat pegawai untuk diangkat menjadi SDM pengelola aset; 8) Keterbatasan jumlah SDM pengelola aset di Bakeuda; 9) Keterbatasan anggaran operasional kegiatan pengelolaan aset; 10) Monev belum dilakukan terhadap kegiatan diklat pengelolaan aset; 11) Penghargaan dan sanksi belum diterapkan terhadap SDM pengelola aset; 12) Kurang optimalnya peranan Inspektorat selaku aparat pengawasan intern pemerintah dalam pengelolaan aset. Hasil kajian ini sejalan dengan penelitian yang dilakukan Putranto (2016) yang menyatakan bahwa faktorfaktor penghambat implementasi kebijakan pengelolaan aset di Kota Bandung adalah kurang akuratnya data dan dokumen terkait aset daerah, sarana dan prasarana kurang memadai, jumlah dan kualitas SDM pengelola aset belum memadai, serta kurang koordinasi internal antar unit kerja.

Kemudian, berbagai kelemahan dalam pelaksanaan aplikasi SIM aset antara lain: 1) Kepala SKPD kurang melakukan pengawasan kepada SDM pengelola aset dalam input (entry) data, sehingga proses input data tidak secara rutin dilakukan oleh SDM pengelola aset; 2) Atasan langsung dari SDM pengelola aset tidak melakukan proses validasi atas input data, sehingga dimungkinkan terjadi kesalahan pada input data; 3) SDM pengelola aset belum memiliki data yang lengkap untuk pencatatan (input data); 4) Penyelenggaraan diklat SIM aset sangat terbatas; 5) SDM pengelola aset terlalu percaya dan bergantung dengan data-data yang ada pada
SIM aset dan tidak memverifikasi secara langsung fisik/wujud barangnya yang ada di lapangan; 6) Kurangnya SDM yang berlatar belakang teknologi informasi bagi operator SIM aset, sehingga berdampak lemahnya koordinasi dalam pengelolaan aset. Hasil kajian ini sejalan dengan penelitian yang dilakukan Rizqi et al. (2010) yang menyatakan bahwa dampak negatif dari adanya Simbada adalah pihak pengelola terlalu bergantung dengan data-data aset pada Simbada dan tidak memverifikasi data aset di lapangan. Sehingga terjadi adanya ketidaksesuaian data aset di Kabupaten Malang.

Menurut Hanis et al. (2010) menyatakan bahwa pengelolaan aset daerah mempunyai peranan yang sangat strategis sebagai salah satu indikator penting pada pengelolaan keuangan daerah dalam mewujudkan akuntabilitas keuangan daerah. Pentingnya kerangka pengelolaan aset di sektor publik pada pemerintah daerah telah diakui dan disadari diseluruh dunia, serta penerapannya tidaklah bersifat sederhana, karena banyak permasalahan yang terkait pengelolaan aset di sektor publik.

\section{Strategi Perbaikan Sistem Kegiatan Penatausahaan Aset Tetap}

Berdasarkan hasil analisis tinjauan keberadaan sistem dan analisis berbagai kelemahan sistem kegiatan penatausahaan aset tetap, maka diperlukan strategi perbaikan sistem kegiatan penatausahaan aset tetap pada Pemkab Purbalingga. Strategi tersebut diawali dengan identifikasi SWOT serta merumuskan strategi untuk memanfaatkan kekuatan dan peluang dalam meminimalkan dampak yang timbul akibat kelemahan dan ancaman yang ada dalam pengelolaan aset tetap di Kabupaten Purbalingga (Tabel 1). 


\section{Tabel 1 Matriks SWOT}

\begin{tabular}{|c|c|c|}
\hline Faktor Eksternal & $\begin{array}{l}\text { Kekuatan (Strengths) } \\
\text { 1. Komitmen pemda menye- } \\
\text { lesaikan permasalahan aset } \\
\text { 2. Tertatanya kelembagaan } \\
\text { pengelolaan aset } \\
\text { 3. Pejabat di bidang aset ditem- } \\
\text { patkan berbasis kompetensi } \\
\text { 4. Adanya target action plan } \\
\text { penyelesaian permasalahan } \\
\text { aset } \\
\text { 5. Monev oleh Inspektorat dalam } \\
\text { pengelolaan aset } \\
\text { 6. Tersedianya SIM aset } \\
\text { 7. Tersedianya sarana pendu- } \\
\text { kung SIM Aset }\end{array}$ & $\begin{array}{l}\text { Kelemahan (Weaknesses) } \\
\text { 1. Belum tersedia prose-dur } \\
\text { SOP pengelolaan aset } \\
\text { yang rinci dan tertulis } \\
\text { 2. Tingkat kompetensi } \\
\text { SDM pengelola aset } \\
\text { belum memadai } \\
\text { 3. Kompensasi dan peng- } \\
\text { hargaan atas prestasi } \\
\text { SDM pengelola aset } \\
\text { belum memadai }\end{array}$ \\
\hline $\begin{array}{l}\text { Peluang (Opportunities) } \\
\text { 1. Pendampingan pengelolaan aset } \\
\text { oleh BPKP } \\
\text { 2. Tersedianya peraturan peme- } \\
\text { rintah terkait pengelolaan aset } \\
\text { 3. Tersedianya ahli dan peneliti } \\
\text { yang berpengalaman dalam } \\
\text { pengelolaan aset } \\
\text { 4. Kegiatan sosialiasi, diklat dan } \\
\text { bimtek pengelolaan aset setiap } \\
\text { tahun } \\
\text { 5. Kemajuan teknologi infor-masi } \\
\text { dalam pengelolaan aset }\end{array}$ & $\begin{array}{l}\text { Strategi SO } \\
\text { 1. Penuntasan permasalahan aset } \\
\text { (S1,S2,S3,S4,S5,S6, } \\
\text { S7,O2,O5) } \\
\text { 2. Peningkatan kerjasama antar } \\
\text { lembaga dalam pengelolaan } \\
\text { aset (S2,S4,S5,S6,S7,O1, } \\
\text { O3, O4) }\end{array}$ & $\begin{array}{l}\text { Strategi WO } \\
\text { 1. Peningkatan kompetensi } \\
\text { SDM pengelola aset } \\
\text { (W1,W2,O1,O2, } \\
\text { O3,O4) } \\
\text { 2. Perbaikan kompensasi } \\
\text { dan penghargaan atas } \\
\text { prestasi kerja dari SDM } \\
\text { pengelola aset (W3,O1, } \\
\text { O2,O3) }\end{array}$ \\
\hline $\begin{array}{l}\text { Ancaman (Threats) } \\
\text { 1. Adanya rekomendasi dari } \\
\text { auditor BPK yang sulit } \\
\text { dilaksanakan } \\
\text { 2. Tidak tersedianya dokumen } \\
\text { yang memadai atas aset eks. } \\
\text { departemen } \\
\text { 3. Perubahan masa kepemim- } \\
\text { pinan bupati } \\
\text { 4. Aset pemda yang digunakan } \\
\text { masyarakat } \\
\text { 5. Perubahan regulasi pemerin-tah } \\
\text { terkait pengelolaan asset }\end{array}$ & $\begin{array}{l}\text { Strategi ST } \\
\text { 1. Peningkatan koordinasi antar } \\
\text { lembaga dalam pengelolaan } \\
\text { aset (S2,S4,S5,S6,S7,T1,T2, } \\
\text { T3,T5) } \\
\text { 2. Pelaksanaan action plan } \\
\text { melalui pengawalan pelaksa- } \\
\text { naan tindak lanjut temuan audit } \\
\text { oleh Inspektorat } \\
\text { (S1,S4,S5,T1,T2,T4,T5) }\end{array}$ & $\begin{array}{l}\text { Strategi WT } \\
\text { 1. } \\
\text { Pelaksanaan action } \\
\text { plan melalui sensus } \\
\text { dan rekonsiliasi data } \\
\text { aset secara rutin } \\
\text { (W1,W2,T1,T2,T5) } \\
\text { 2. } \\
\text { Pelaksanaan action } \\
\text { plan melalui pening- } \\
\text { katan peranan Ins- } \\
\text { pektorat dalam } \\
\text { pengamanan asset } \\
\text { (W1,W2,T1,T2,T4) }\end{array}$ \\
\hline
\end{tabular}

1. Strategi Strengths-Opportunities (S-O)

Strategi pertama yaitu penuntasan permasalahan aset tetap dengan dukungan sumberdaya yang dimiliki Pemkab Purbalingga. Strategi ini diharapkan dapat memberikan solusi penyelesaian permasalahan aset tetap, terutama terkait penyajian nilai aset tetap dalam laporan neraca pemda yang tidak dapat diyakini kewajarannya. Strategi kedua yang dirumuskan pada strategi SO ini adalah peningkatan kerjasama antar lembaga melalui pendampingan pengelolaan aset dari BPKP, kerjasama dengan BPN untuk sertifikasi aset tanah, dan kerjasama dengan CV. SEML Semarang untuk 
pengembangan dan pemeliharaan SIM aset. Kerjasama ini perlu dilakukan agar pengelolaan aset tetap dapat berjalan secara baik, terutama kegiatan penatausahaan aset tetap.

2. Strategi Weaknesses-Opportunities (W-O)

Strategi pertama adalah peningkatan kompetensi SDM pengelola aset. Diharapkan SDM yang kompeten dapat bekerja secara profesional, terampil dan handal dalam melaksanakan tugas dan tanggungjawab pekerjaannya, serta mampu menyesuaikan diri secara baik dengan lingkungannya. SDM yang kompeten mencakup aspek pengetahuan (knowledge), keterampilan (skill) dan sikap perilaku (attitude). Strategi kedua adalah perbaikan kompensasi dan penghargaan atas prestasi kerjadari SDM pengelola aset. SDM pengelola aset mempunyai peranan penting dan strategis dalam pengelolaan aset. Kompensasi dan penghargaan merupakan salah satu bentuk balas jasa yang diberikan organisasi kepada pegawai atas prestasi kerja yang telah dicapai. Kompensasi dan penghargaan juga sebagai dorongan atau motivasi kepada pegawai untuk lebih meningkatkan prestasi kerja 68 dan pengabdian.

3. Strategi Strengths-Threats (S-T)

Strategi S-T pertama adalah peningkatan koordinasi antar lembaga, yaitu koordinasi dengan BPK untuk tindak lanjut temuan audit, koordinasi dengan BPN untuk sertifikasi aset tanah, koordinasi dengan CV. SEML Semarang untuk pengembangan dan pemeliharaan SIM aset. Koordinasi ini perlu dilakukan agar pengelolaan aset tetap dapat berjalan secara baik, terutama kegiatan penatausahaan aset tetap. Strategi S-T yang kedua adalah pelaksanaan rencana tindak lanjut (action plan) melalui pengawalan pelaksanaan tindak lanjut temuan audit oleh Inspektorat. Inspektorat melakukan kegiatan monitoring dan evaluasi tiap triwulan terhadap pencapaian target rencana tindak lanjut temuan audit BPK-RI.

4. Strategi Weaknesses-Threats (W-T) Strategi pertama adalah pelaksanaan rencana tindak lanjut (action plan) melalui sensus dan rekonsiliasi data aset secara rutin. Rekonsiliasi data aset dan sensus barang daerah dilakukan secara rutin selama lima tahun sekali untuk mengecek kebenaran catatan pada buku inventaris dan kartu inventaris dengan kondisi aset di lapangan, sehingga tercapai data aset yang valid, akurat dan dapat dipertanggungjawabkan. Strategi kedua adalah pelaksanaan rencana tindak lanjut (action plan) melalui peningkatan peranan Inspektorat dalam pengamanan aset. Action plan mengamanatkan Inspektorat untuk meningkatkan peranannya dalam menangani permasalahan aset, terutama dalam pengamanan aset daerah.

Berdasarkan usulan strategi tersebut dirumuskan program-program yang akan dilakukan untuk mencapai sasaran, yang dapat dilihat pada Tabel 2. 
Tabel 2 Strategi Perbaikan Sistem Kegiatan Penatausahaan Aset Tetap

\begin{tabular}{|c|c|c|}
\hline No & Strategi & Program \\
\hline 1 & Penuntasan permasalahan asset & $\begin{array}{l}\text { - Pembenahan aset dan validasi data aset } \\
\text { - Sosialisasi sistem/prosedur pengelolaan aset dan } \\
\text { kebijakan akuntansi daerah }\end{array}$ \\
\hline 2 & $\begin{array}{l}\text { Peningkatan kerjasama antar lembaga } \\
\text { dalam pengelolaan aset }\end{array}$ & $\begin{array}{l}\text { - Pendampingan pengelolaan aset dari BPKP, } \\
\text { kerjasama dengan BPN untuk sertifikasi aset tanah, } \\
\text { dan kerjasama dengan CV. SEML untuk } \\
\text { pengembangan dan pemeliharaan SIM asset }\end{array}$ \\
\hline 3 & $\begin{array}{lll}\text { Peningkatan } & \text { kompetensi } & \text { SDM } \\
\text { pengelola aset } & & \end{array}$ & $\begin{array}{l}\text { - Sosialisasi, diklat dan bimtek pengelolaan aset } \\
\text { secara terjadwal dan berkelanjutan }\end{array}$ \\
\hline 4 & $\begin{array}{l}\text { Perbaikan kompensasi dan penghargaan } \\
\text { atas prestasi kerja dari SDM pengelola } \\
\text { aset }\end{array}$ & $\begin{array}{l}\text { - Peningkatan penghasilan tambahan kepada SDM } \\
\text { pengelola aset } \\
\text { - Jabatan fungsional umum bagi SDM pengelola asset }\end{array}$ \\
\hline 5 & $\begin{array}{l}\text { Peningkatan koordinasi antar lembaga } \\
\text { dalam pengelolaan aset }\end{array}$ & $\begin{array}{l}\text { - Koordinasi dengan BPK untuk tindak lanjut temuan } \\
\text { audit, koordinasi dengan BPN untuk sertifikasi aset } \\
\text { tanah, dan koordinasi dengan CV. SEML untuk } \\
\text { pengembangan dan pemeliharaan SIM aset }\end{array}$ \\
\hline 6 & $\begin{array}{l}\text { Pelaksanaan action plan melalui } \\
\text { pengawalan pelaksanaan tindak lanjut } \\
\text { temuan audit oleh Inspektorat }\end{array}$ & $\begin{array}{l}\text { - Monitoring dan evaluasi tiap triwulan terhadap } \\
\text { pencapaian target rencana tindak lanjut temuan } \\
\text { audit }\end{array}$ \\
\hline 7 & $\begin{array}{l}\text { Pelaksanaan action plan melalui sensus } \\
\text { dan rekonsiliasi data aset secara rutin }\end{array}$ & - Sensus dan rekonsiliasi data aset secara rutin \\
\hline 8 & $\begin{array}{l}\text { Pelaksanaan action plan melalui } \\
\text { peningkatan peranan Inspektorat dalam } \\
\text { pengamanan aset }\end{array}$ & $\begin{array}{l}\text { - Peningkatan peranan } \\
\text { pengamanan asset }\end{array}$ \\
\hline
\end{tabular}

Tahapan pencapaian sasaran perbaikan sistem kegiatan penatausahaan aset tetap Pemkab Purbalingga dilakukan dengan pelaksanaan program secara bertahap dengan tiga periode waktu. Lebih jelas dapat di lihat pada Gambar 1.

\section{SIMPULAN DAN SARAN}

\section{Simpulan}

Berdasarkan hasil analisis yang dilakukan pada penelitian ini, maka diperoleh kesimpulan sebagai berikut:

1. Sistem pengelolaan aset di Kabupaten Purbalingga berpedoman pada PP Nomor 27 Tahun 2014 dan Permendagri Nomor 19 Tahun 2016. Hal ini sesuai dengan Surat Keputusan Bupati Purbalingga Nomor 180/9802/XI/2016 tanggal $30 \quad$ November 2016. Pelaksanaan kegiatan penatausahaan dalam pengelolaan aset di Kabupaten Purbalingga masih buruk.

2. Berbagai kelemahan sistem kegiatan penatausahaan aset di Kabupaten Purbalingga antara lain: 1) Tidak adanya prosedur SOP yang rinci dan tertulis pada kegiatan penatausahaan aset 2) Kurang optimalnya kinerja tim pengarah dan tim teknis penataan dan pengelolaan aset; 3) Kurangnya pengawasan pelaksanaan pekerjaan oleh Kepala SKPD kepada SDM pengelola aset; 4) Kegiatan pengamanan terhadap aset belum berjalan secara tertib; 5) Kegiatan pemeliharaan terhadap aset belum direncanakan secara tertib; 6) Lemahnya koordinasi antar SKPD dalam pengelolaan aset; 7) Belum ada aturan tertulis tentang syarat-syarat pegawai untuk diangkat menjadi SDM pengelola aset; 8) Keterbatasan jumlah SDM pengelola aset di Bakeuda; 9) Keterbatasan anggaran kegiatan pengelolaan aset; 10) Monev belum dilakukan terhadap kegiatan diklat pengelolaan aset; 11) Penghargaan dan sanksi belum diterapkan terhadap SDM pengelola aset; 12) Kurang optimalnya peranan Inspektorat selaku aparat pengawasan intern pemerintah dalam pengelolaan aset. 

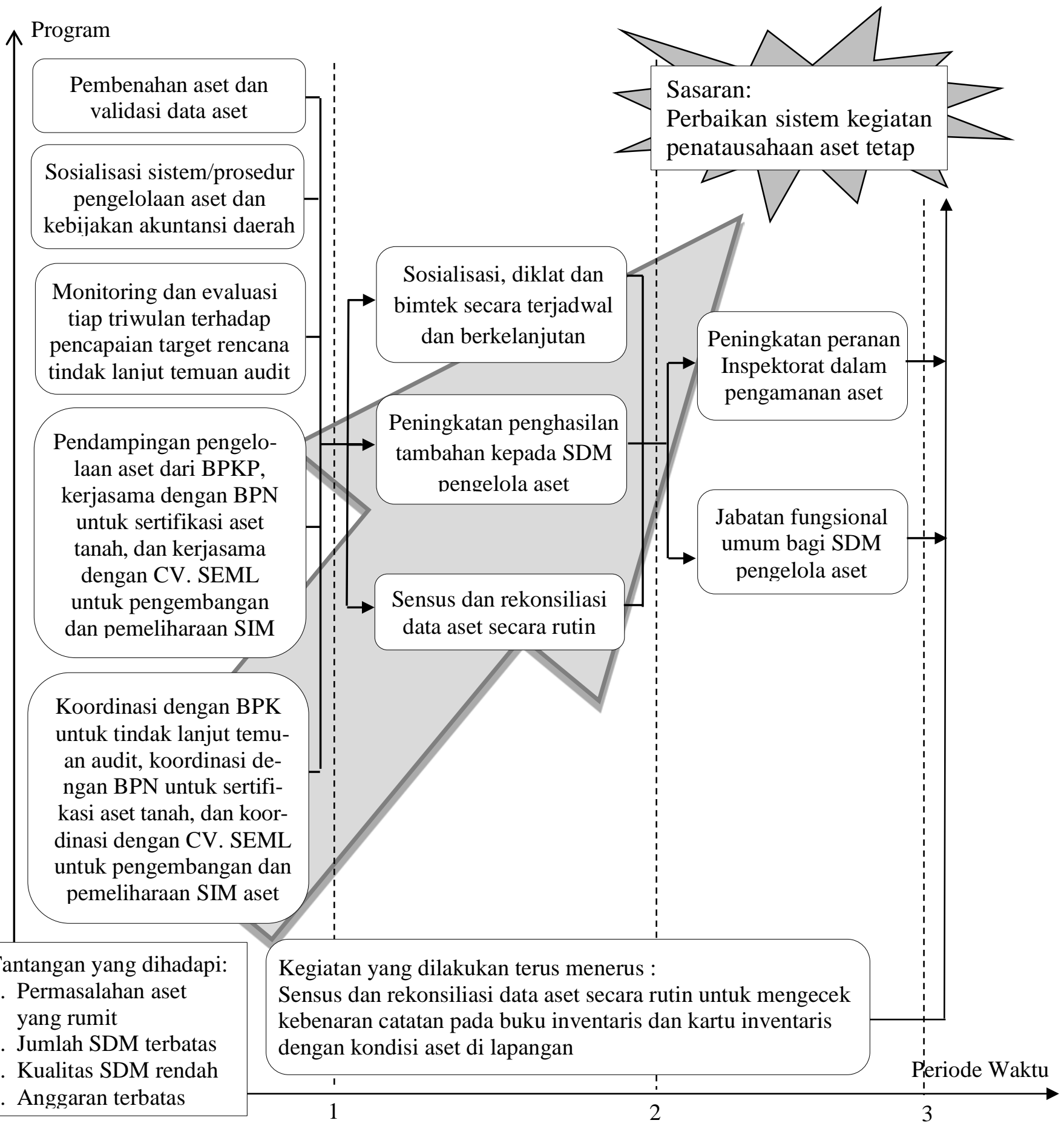

Tantangan yang dihadapi:

1. Permasalahan aset yang rumit

2. Jumlah SDM terbatas

3. Kualitas SDM rendah

4. Anggaran terbatas
Kegiatan yang dilakukan terus menerus

Sensus dan rekonsiliasi data aset secara rutin untuk mengecek kebenaran catatan pada buku inventaris dan kartu inventaris dengan kondisi aset di lapangan

Gambar 1 Arsitektur strategik perbaikan sistem kegiatan penatausahaan aset tetap Pemkab Purbalingga 
3. Analisis SWOT dan arsitektur strategi yang dilakukan menghasilkan strategi dan program dalam upaya perbaikan sistem kegiatan penatausahaan aset tetap Pemkab Purbalingga dengan tiga periode waktu, yaitu penuntasan permasalahan aset tetap, peningkatan kerjasama antar lembaga dalam pengelolaan aset, peningkatan kompetensi SDM pengelola aset, perbaikan kompensasi dan penghargaan atas prestasi kerja dari SDM pengelola aset, peningkatan koordinasi antar lembaga dalam pengelolaan aset, pelaksanaan action plan melalui pengawalan pelaksanaan tindak lanjut temuan audit oleh Inspektorat, pelaksanaan action plan melalui sensus dan rekonsiliasi data aset secara rutin, pelaksanaan action plan melalui peningkatan peranan Inspektorat dalam pengamanan aset.

\section{Saran}

Pemkab Purbalingga diharapkan dapat mengimplementasikan strategi perbaikan sistem kegiatan penatausahaan aset tetap berdasarkan hasil analisis SWOT dan arsitektur strategik. Pejabat pengelola aset perlu meningkatkan pengawasan, monitoring dan evaluasi terhadap kegiatan pengelolaan aset, mulai dari tahap perencanaan, pengadaan sampai tahap penghapusan aset. Penghargaan WTP dari BPK-RI atas laporan keuangan Pemkab Purbalingga Tahun Anggaran 2016 adalah prestasi yang pertama kali dan sangat menggembirakan. Prestasi ini harus dijadikan titik awal untuk menuju pengelolaan keuangan dan aset yang tertib. Pemkab Purbalingga harus dapat mempertahankan prestasi WTP dengan meningkatkan kualitas laporan keuangan. Oleh karena itu, diperlukan kerja keras dan kerja ikhlas dari seluruh pegawai Pemkab Purbalingga.

\section{DAFTAR PUSTAKA}

Azhar I, Darwanis, Abdullah S. 2011. Pengaruh Kualitas Aparatur Daerah, Regulasi, dan Sistem Informasi terhadap
Manajemen Aset. Jurnal Akuntansi. 2(1):15-26.

Hanis MH, Trigunarsyah B, Susilawati C. 2010. Elements of Public Asset Management Framework for Local Governments in Developing Countries. In: 8th International Conference on Construction and Real Estate Management (ICCREM 2010), 1-3 Desember 2010, Royal on the Park Hotel, Brisbane. QUT Digital Repository.

[Kemendagri] Kementerian Dalam Negeri. 2016. Peraturan Menteri Dalam Negeri Nomor 19 Tahun 2016 tentang Pedoman Pengelolaan Barang Milik Daerah. Jakarta [ID]. Sekretariat Jenderal.

Nancy S. 2015. Implementasi Kebijakan Pengelolaan Barang Milik Daerah pada Dinas Pendidikan, Pemuda dan Olah Raga Kabupaten Sigi. Jurnal Katalogis. 3(2):160-172.

Pemerintah Republik Indonesia. 2014. Peraturan Pemerintah Nomor 27 Tahun 2014 tentang Pengelolaan Barang Milik Negara/Daerah. Jakarta (ID): Sekretariat Negara RI.

Putranto WJ. 2016. Implementasi Kebijakan Pengelolaan Barang Milik Daerah di Pemerintah Kota Bandung (Studi Kasus Sekretariat Daerah Kota Bandung). Jurnal Administrasi. 1(1):1-14.

Rangkuti F. 2006. Analisis SWOT teknik membedah kasus bisnis. Jakarta [ID]. Gramedia Jakarta.

Rizqi LN, Domai T, Wachid A. 2013. Penatausahaan Aset Pemerintah Daerah Melalui Sistem Informasi Manajemen Barang Daerah (Simbada) di Kabupaten Malang. Jurnal Administrasi Publik. 1(1):93-101.

Wonggow, Ilat V, Affandi D. 2014. Kajian Mengenai Pengelolaan Barang Milik Daerah pada Pemerintah Kota Manado menurut Permendagri 17 Tahun 2007. Jurnal EMBA. 2(1):582-593.

Yusuf M. 215. 8 Langkah Pengelolaan Aset Daerah menuju Pengelolaan Keuangan Daerah Terbaik. Jakarta (ID): Salemba Empat. 